\title{
Dermatoglyphics: A Diagnostic Aid?
}

\author{
I. C. FULLER \\ Sedgefield, Stockton-on-Tees
}

\begin{abstract}
Summary. Dermatoglyphics of patients suffering from diabetes, schizophrenia, duodenal ulcer, asthma, and various cancers have been contrasted and significant differences in the digital ridge counts, maximum atd angles, and distal palmar loop ridge counts have been found. A discriminant analysis of the digital ridge counts was performed and the function was used to attempt differential diagnosis between these conditions on dermatoglyphic evidence alone. This diagnostic trial failed, and possible reasons for its failure are discussed. Attention is drawn to the possibility that prognostic implications of dermatoglyphics might be relevant to screening techniques.
\end{abstract}

With the demonstration of a strong genetic component in ridge counts by Sarah Holt (eg, Holt, 1961), which came as the culmination of a large number of early exploratory papers on the inheritance of dermatoglyphic traits (summarized in Cummins and Midlo, 1961), the relationship of finger and palm prints with genetic disease was an obvious topic for exploration. During the last decade a number of claims have been made for their association with various diseases, eg, leukaemia (Verbov, 1970), rubella embryopathy (Achs, Harper, and Siegal, 1966), schizophrenia (Mellor, 1968). In particular their relationship to disorders of the sex chromosomes and some autosomes has been well established (Penrose, 1967) and methods of using these as aids in diagnosis devised (Walker, 1957). Claims for association with other non-chromosomal types of familial disorder however have tended to proliferate on the basis of simple comparison of dermatoglyphic characters or their frequencies in patients with the disease and in reputedly normal samples. The fundamental assumption is that since many genes take part in the formation of dermatoglyphic characters, it is possible that genes which predispose to familial disease may, by pleiotropy, also influence the ridge patterns so that particular constellations of dermatoglyphic features may be characteristic of a particular disease. Yet there has been no attempt to carry the analysis further, and to enquire whether possession of the

Received 23 January 1973. dermatoglyphic characters that are apparently distinctive of a particular disease in fact allows diagnosis to be made. This has been the object of the present investigation: to enquire into usefulness of dermatoglyphic characters as an aid in diagnosis. It took the form of an examination of patients known to have particular diseases, first, to see whether discrimination could be made between them on the basis of dermatoglyphic features and secondly, to use the discriminant so produced to see whether a correct diagnosis could be made blind in a series of patients each suffering from one of the diseases.

\section{Material}

Prints of fingers and palms were obtained from males with diabetes, schizophrenia, duodenal ulcer, asthma, and various cancers and from females with diabetes, schizophrenia, and various cancers. The patients were obtained from my own and nearby practices; from Sedgefield General Hospital, Stockton and Thornaby and Winterton Hospitals, from the Diabetic Clinic at Dryburn Hospital, and the Children's Diabetic Clinic at Middlesborough General Hospital. A group of asthmatics in the Evenwood Residential School for physically handicapped children was also included. These patients were selected only if they were willing to cooperate and if they had hands from which good clear prints could be obtained.

The diagnoses in the patients were confirmed as follows: diabetes in patients in the practice was confirmed by glucose tolerance tests. Patients on insulin when coming to the district, those in hospital for diabetes, or those reattending diabetic clinics were regarded as having this 
disease. Asthmatic patients were diagnosed by a paediatrician having a particular interest in chest complaints. Cancers were diagnosed on the criteria of histology (48\% of patients), gross anatomy at operation or necropsy $(28 \%)$, radiology (10\%), attendance for deep $x$-ray therapy ( $2 \%)$, cystoscopy ( $1 \%)$, bronchoscopy $(0.5 \%)$, and cervical smear $(0.5 \%)$; in $9 \%$ the mode of diagnosis was unrecorded. For the duodenal ulcer patients, $30 \%$ were diagnosed at laparotomy, $59 \%$ by radiology, and again for $11 \%$ the mode of diagnosis was unrecorded. Schizophrenia was diagnosed from hospital records and confirmed by consultant psychiatrists who classified the patients as paranoid or non-paranoid. Where patients were known to have two of the pathologies being studied they were included in both series. Early in the investigation it became apparent that the diabetics fell into two different categories, those with age at onset before or after the 25th birthday, and these two groups were treated as having separate conditions.

The prints were analysed and classified as they became $\stackrel{\overparen{D}}{+}$ available, and collection of the material went on for some $\Rightarrow$ three years. Most schizophrenics and asthmatics, being $\stackrel{5}{\oplus}$ readily available, were collected early in the investigation, $\bar{C}$ but collection of the prints was a continuous process, and $\bar{\sigma}$ no disease group was collected at any one time to the ex- $\overline{\bar{c}}$ clusion of all others.

The dermatoglyphic characters of the prints were analysed according to the standard methods as set out in $\infty$ Cummins and Midlo (1961). For each finger the ridges $\vec{\circ}$ were counted on the ulnar and radial side, and the greater taken as the ridge count for that finger. The variance $\vec{\omega}$ between fingers was calculated. The pattern on each $\sigma$ finger was assigned, as described in Cummins and Midlo (1961, pp. 60-66), to one of the following categories:

TABLE I

DIGITAL AND TOTAL RIDGE COUNTS

\begin{tabular}{|c|c|c|c|c|c|c|c|c|c|c|}
\hline & \multicolumn{6}{|c|}{ Male } & \multicolumn{4}{|c|}{ Female } \\
\hline & 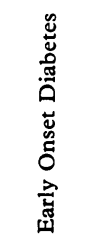 & 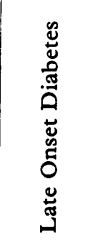 & 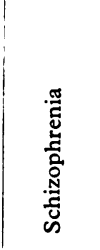 & 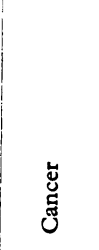 & 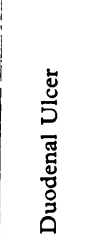 & 壳 & 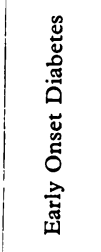 & 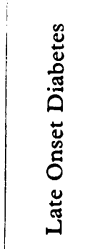 & 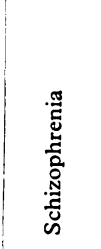 & 岕 \\
\hline Total No. of Cases & 22 & 72 & 74 & 70 & 81 & 40 & 25 & 69 & 80 & 90 \\
\hline $\begin{array}{l}\text { Right hand } \\
\text { Thumb } \\
\text { Mean* } \\
\text { SD } \\
\text { Index finger }\end{array}$ & $\begin{array}{r}17.55 \\
6.96\end{array}$ & $\begin{array}{r}18 \cdot 47 \\
6 \cdot 12\end{array}$ & $\begin{array}{r}17 \cdot 73 \\
6 \cdot 86\end{array}$ & $\begin{array}{r}18 \cdot 19 \\
5 \cdot 83\end{array}$ & $\begin{array}{r}18 \cdot 25 \\
6 \cdot 43\end{array}$ & $\begin{array}{r}19 \cdot 32 \\
5 \cdot 13\end{array}$ & $\begin{array}{r}19 \cdot 52 \\
5 \cdot 08\end{array}$ & $\begin{array}{r}15 \cdot 17 \\
6 \cdot 49\end{array}$ & $\begin{array}{r}14.52 \\
6.76\end{array}$ & $\begin{array}{r}15 \cdot 85 \\
6 \cdot 89\end{array}$ \\
\hline $\begin{array}{l}\text { Meant } \\
\text { SD } \\
\text { Middle finger }\end{array}$ & $\begin{array}{r}14.55 \\
6.75\end{array}$ & $\begin{array}{r}10.43 \\
7.08\end{array}$ & $\begin{array}{r}10 \cdot 92 \\
7 \cdot 25\end{array}$ & $\begin{array}{l}9 \cdot 14 \\
7 \cdot 49\end{array}$ & $\begin{array}{r}11 \cdot 26 \\
7 \cdot 17\end{array}$ & $\begin{array}{r}13.13 \\
7.06\end{array}$ & $\begin{array}{r}10 \cdot 68 \\
5 \cdot 73\end{array}$ & $\begin{array}{r}10 \cdot 22 \\
6.91\end{array}$ & $\begin{array}{r}11 \cdot 25 \\
7 \cdot 54\end{array}$ & $\begin{array}{r}10.42 \\
7.83\end{array}$ \\
\hline $\begin{array}{l}\text { Mean } \\
\text { SD } \\
\text { Ring finger }\end{array}$ & $\begin{array}{r}13 \cdot 05 \\
8 \cdot 35\end{array}$ & $\begin{array}{r}11.07 \\
5.99\end{array}$ & $\begin{array}{r}11 \cdot 80 \\
6 \cdot 20\end{array}$ & $\begin{array}{r}9 \cdot 47 \\
5 \cdot 67\end{array}$ & $\begin{array}{r}11 \cdot 62 \\
5 \cdot 86\end{array}$ & $\begin{array}{r}11 \cdot 55 \\
5 \cdot 50\end{array}$ & $\begin{array}{r}13 \cdot 04 \\
4 \cdot 43\end{array}$ & $\begin{array}{r}9 \cdot 80 \\
5 \cdot 85\end{array}$ & $\begin{array}{r}10 \cdot 69 \\
6 \cdot 70\end{array}$ & $\begin{array}{r}10 \cdot 52 \\
6.36\end{array}$ \\
\hline $\begin{array}{l}\text { Mean*t } \\
\text { SD } \\
\text { Little finger }\end{array}$ & $\begin{array}{r}18 \cdot 27 \\
6 \cdot 51\end{array}$ & $\begin{array}{r}15 \cdot 40 \\
5 \cdot 69\end{array}$ & $\begin{array}{r}15 \cdot 74 \\
5.53\end{array}$ & $\begin{array}{r}13.93 \\
5.89\end{array}$ & $\begin{array}{r}15.47 \\
5.95\end{array}$ & $\begin{array}{r}17 \cdot 17 \\
4 \cdot 67\end{array}$ & $\begin{array}{r}17 \cdot 80 \\
4 \cdot 23\end{array}$ & $\begin{array}{r}14.75 \\
6.91\end{array}$ & $\begin{array}{r}13.97 \\
6.87\end{array}$ & $\begin{array}{r}13 \cdot 87 \\
7 \cdot 19\end{array}$ \\
\hline $\begin{array}{l}\text { Mean } \\
\text { SD } \\
\end{array}$ & $\begin{array}{r}14 \cdot 36 \\
4 \cdot 74 \\
\end{array}$ & $\begin{array}{r}12.68 \\
4.87 \\
\end{array}$ & $\begin{array}{r}13.53 \\
5.25 \\
\end{array}$ & $\begin{array}{r}11 \cdot 76 \\
4 \cdot 89 \\
\end{array}$ & $\begin{array}{r}13.32 \\
5.05 \\
\end{array}$ & $\begin{array}{r}14 \cdot 17 \\
5 \cdot 38 \\
\end{array}$ & $\begin{array}{r}12 \cdot 40 \\
4 \cdot 61 \\
\end{array}$ & $\begin{array}{r}12.33 \\
6.07 \\
\end{array}$ & $\begin{array}{r}11 \cdot 85 \\
5 \cdot 11 \\
\end{array}$ & $\begin{array}{r}12.14 \\
5.82 \\
\end{array}$ \\
\hline $\begin{array}{l}\text { Left hand } \\
\text { Thumb } \\
\text { Mean } \\
\text { SD } \\
\text { Index finger }\end{array}$ & $\begin{array}{r}15 \cdot 59 \\
6.08\end{array}$ & $\begin{array}{r}15 \cdot 24 \\
5 \cdot 89\end{array}$ & $\begin{array}{r}15.61 \\
7.03\end{array}$ & $\begin{array}{r}15.47 \\
6.08\end{array}$ & $\begin{array}{r}15.98 \\
5.95\end{array}$ & $\begin{array}{r}16 \cdot 17 \\
4 \cdot 76\end{array}$ & $\begin{array}{r}14 \cdot 24 \\
6 \cdot 43\end{array}$ & $\begin{array}{r}12.72 \\
6 \cdot 30\end{array}$ & $\begin{array}{r}12.95 \\
6.42\end{array}$ & $\begin{array}{r}13.67 \\
6.26\end{array}$ \\
\hline $\begin{array}{l}\text { Index ninger } \\
\text { Mean } \\
\text { SD } \\
\text { Middle finger }\end{array}$ & $\begin{array}{r}11.95 \\
7.56\end{array}$ & $\begin{array}{l}9 \cdot 26 \\
6 \cdot 66\end{array}$ & $\begin{array}{r}10 \cdot 73 \\
7 \cdot 22\end{array}$ & $\begin{array}{l}9 \cdot 56 \\
6 \cdot 67\end{array}$ & $\begin{array}{r}10 \cdot 05 \\
6 \cdot 23\end{array}$ & $\begin{array}{r}11 \cdot 45 \\
7 \cdot 13\end{array}$ & $\begin{array}{r}12.64 \\
5.44\end{array}$ & $\begin{array}{l}9 \cdot 78 \\
6 \cdot 62\end{array}$ & $\begin{array}{r}10 \cdot 80 \\
7 \cdot 12\end{array}$ & $\begin{array}{l}9 \cdot 20 \\
7 \cdot 55\end{array}$ \\
\hline $\begin{array}{l}\text { Mean* } \\
\text { SD } \\
\text { Ring finger }\end{array}$ & $\begin{array}{r}12 \cdot 36 \\
6 \cdot 66\end{array}$ & $\begin{array}{r}11.22 \\
6.05\end{array}$ & $\begin{array}{r}12.79 \\
6.05\end{array}$ & $\begin{array}{l}9 \cdot 99 \\
5 \cdot 73\end{array}$ & $\begin{array}{r}10 \cdot 67 \\
6 \cdot 44\end{array}$ & $\begin{array}{r}13 \cdot 15 \\
5 \cdot 28\end{array}$ & $\begin{array}{r}13 \cdot 60 \\
5 \cdot 54\end{array}$ & $\begin{array}{r}10 \cdot 07 \\
7.01\end{array}$ & $\begin{array}{r}11 \cdot 32 \\
6.99\end{array}$ & $\begin{array}{r}10 \cdot 33 \\
7 \cdot 14\end{array}$ \\
\hline $\begin{array}{l}\text { Mean } \\
\text { SD } \\
\text { Little finger }\end{array}$ & $\begin{array}{r}17 \cdot 14 \\
6.55\end{array}$ & $\begin{array}{r}14.90 \\
5.31\end{array}$ & $\begin{array}{r}16 \cdot 16 \\
5.98\end{array}$ & $\begin{array}{r}13.27 \\
5.90\end{array}$ & $\begin{array}{r}15.42 \\
5.79\end{array}$ & $\begin{array}{r}17 \cdot 15 \\
4 \cdot 61\end{array}$ & $\begin{array}{r}17.56 \\
4.66\end{array}$ & $\begin{array}{r}14 \cdot 65 \\
7.78\end{array}$ & $\begin{array}{r}14.66 \\
6.34\end{array}$ & $\begin{array}{r}13.83 \\
8.04\end{array}$ \\
\hline $\begin{array}{l}\text { Mean } \\
\text { SD } \\
\end{array}$ & $\begin{array}{r}14 \cdot 45 \\
4 \cdot 31 \\
\end{array}$ & $\begin{array}{r}12 \cdot 50 \\
4 \cdot 73 \\
\end{array}$ & $\begin{array}{r}13 \cdot 59 \\
5 \cdot 47 \\
\end{array}$ & $\begin{array}{r}11.96 \\
4.72 \\
\end{array}$ & $\begin{array}{r}12 \cdot 47 \\
5 \cdot 28 \\
\end{array}$ & $\begin{array}{r}13 \cdot 82 \\
4 \cdot 32 \\
\end{array}$ & $\begin{array}{r}12.68 \\
4.63 \\
\end{array}$ & $\begin{array}{r}11 \cdot 65 \\
5 \cdot 27 \\
\end{array}$ & $\begin{array}{r}11 \cdot 21 \\
5 \cdot 77 \\
\end{array}$ & $\begin{array}{r}11.93 \\
5.67 \\
\end{array}$ \\
\hline $\begin{array}{l}\text { Total ridge count } \\
\text { Mean } \\
\text { SD }\end{array}$ & $\begin{array}{r}149 \cdot 27 \\
53.97\end{array}$ & $\begin{array}{r}131 \cdot 17 \\
44 \cdot 78\end{array}$ & $\begin{array}{r}138 \cdot 60 \\
50 \cdot 00\end{array}$ & $\begin{array}{r}122 \cdot 73 \\
44 \cdot 81\end{array}$ & $\begin{array}{r}134 \cdot 48 \\
45 \cdot 41\end{array}$ & $\begin{array}{r}147 \cdot 09 \\
39 \cdot 37\end{array}$ & $\begin{array}{r}144 \cdot 15 \\
33 \cdot 78\end{array}$ & $\begin{array}{r}121 \cdot 15 \\
51 \cdot 14\end{array}$ & $\begin{array}{r}123.23 \\
52.79\end{array}$ & $\begin{array}{r}121 \cdot 78 \\
55 \cdot 51\end{array}$ \\
\hline
\end{tabular}

* Analysis of variance of these means is significant at the $5 \%$ level for female (right hand) and male (left hand).

* Analysis of variance of these means is significant at the $5 \%$ level for female (rig

$\ddagger$ Analysis of variance of these means is significant at the $2.5 \%$ level for males.
$\ddagger$ Analysis of variance of these means is significant at the $1 \%$ level for males. 
arch, tented arch, radial loop, ulnar loop, whorl, central pocket ulnar or radial loop, twinned loop, lateral pocket, composite or accidental. For the palms the main line terminations were identified, and the configuration in each interdigital area, the hypothenar and the thenar/first interdigital area categorized. The position of the axial triradius was classified, the maximum atd angles (Penrose, 1954), and the $a b$ (Pons, 1964) and $A-d$ (Glanville, 1965) ridge counts measured.

\section{Results}

Striking differences emerged among the series of patients with different diseases. For example Table I shows, for each of the diseases examined, the mean and standard deviation of the ridge count on each finger and the total ridge count together with the number of cases. The means of the digital ridge counts were compared by analysis of variance. Variation between disease groups was highly significant (at $1 \%$ ) among the male series for the left ring finger; it was significant at $2.5 \%$ in males for the right index and ring fingers; and at 5\% among the female series for the right thumb and ring finger, and among the male series for the left middle finger. The $\chi^{2}$ test was used to examine the number of cases in each disease group falling into different categories of interdigital count variance, of pattern distribution, and of main line terminations. Here significant differences, some of which were very significant, emerged in the frequency of pattern types on the different fingers, in the different palmar zones, and in the main line endings. Analysis of variance by the non-parametric method of Kruskal and Wallis (Siegal, 1956) was applied to the palmar loop ridge counts, maximum atd angles, and $A-d$ ridge counts, the first two showing highly significant differences.

Very large numbers of statistical tests are possible on dermatoglyphic material, so that 'significant' effects may occur by chance, particularly in a large number of tests. Table II sets out the number of different tests done on this material including the number in which 'significance' at a given level is expected to occur and the number observed to be significant at that level. There is obviously no contribution to differentiation from the finger print pattern, the palmar main line terminations, the palmar configuration areas, the $a b$ or the $A-d$ ridge counts. However the digital ridge counts show more differences than expected in both males and females, so do the maximum atd angles and the distal palmar loop ridge counts. All in all, these differences were sufficiently striking to make an attempt at a discriminant analysis worthwhile. This was directed primarily to the digital ridge counts.

Discriminant analysis was made by computer after excluding known cases of dual pathology. The discriminant function was first calculated using the higher ridge count on each digit, secondly using both ulnar and radial counts on each digit and the $a b$ ridge counts on the palms. Using a package

TABLE II

EXPECTED AND OBSERVED SIGNIFICANT DIFFERENCES

\begin{tabular}{|c|c|c|c|c|c|c|c|c|c|c|c|c|c|c|c|c|c|c|}
\hline & \multicolumn{9}{|c|}{ Males } & \multicolumn{9}{|c|}{ Females } \\
\hline & \multirow[b]{2}{*}{ 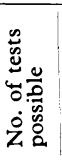 } & \multicolumn{2}{|c|}{$5 \%$} & \multicolumn{2}{|c|}{$2 \%$} & \multicolumn{2}{|c|}{$1 \%$} & \multicolumn{2}{|c|}{$0 \cdot 1 \%$} & \multirow[b]{2}{*}{ 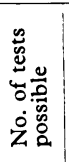 } & \multicolumn{2}{|c|}{$5 \%$} & \multicolumn{2}{|c|}{$2 \%$} & \multicolumn{2}{|c|}{$1 \%$} & \multicolumn{2}{|c|}{$0 \cdot 1 \%$} \\
\hline & & 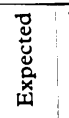 & $\begin{array}{c}\bar{D} \\
己_{0}^{2} \\
\tilde{u} \\
0 \\
0\end{array}$ & 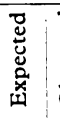 & $\begin{array}{l}\overline{0} \\
\text { 岂 } \\
0 \\
0 \\
0\end{array}$ & 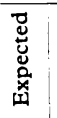 & 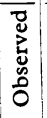 & 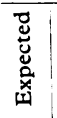 & $\begin{array}{l}\vec{z} \\
\stackrel{0}{u} \\
0 \\
0 \\
0\end{array}$ & & 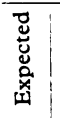 & 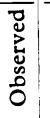 & 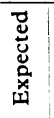 & $\begin{array}{l}\bar{d} \\
\stackrel{\vec{u}}{\mathbf{u}} \\
0 \\
0\end{array}$ & 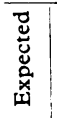 & $\begin{array}{l}\bar{J} \\
\vec{D} \\
.0 \\
0 \\
0\end{array}$ & 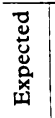 & 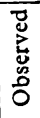 \\
\hline $\begin{array}{l}\text { Digital ridge counts and total ridge count: } \\
\text { analysis of variance }\end{array}$ & 11 & 0.6 & 1 & 0.2 & 2 & $0 \cdot 1$ & 1 & 0 & 0 & 11 & 0.6 & 1 & $0 \cdot 2$ & 0 & $0 \cdot 1$ & 1 & 0 & 0 \\
\hline Variance of digital ridge counts ${ }^{*}: \chi^{2}$ tests & 30 & 1.5 & $\overline{0}$ & 0.6 & $\overline{0}$ & $0 \cdot 3$ & 1 & 0 & $\overline{0}$ & 16 & $\overline{0.8}$ & 0 & $0 \cdot 3$ & 0 & $\overline{0.2}$ & $\overline{0}$ & 0 & 0 \\
\hline Finger print patterns $*: x^{2}$ tests & 216 & $10 \cdot 8$ & 4 & 4 & 0 & 2 & 3 & $0 \cdot 2$ & 2 & 144 & 7 & $\overline{1}$ & 3 & 0 & $1 \cdot 4$ & 0 & $0 \cdot 1$ & 0 \\
\hline Palms-main line terminations ${ }^{*}: x^{2}$ tests & 194 & 10 & $\overline{2}$ & 4 & 3 & 2 & 0 & $0 \cdot 2$ & $\overline{0}$ & 122 & 6 & 0 & $2 \cdot 4$ & 1 & $1 \cdot 2$ & 0 & $0 \cdot 1$ & 0 \\
\hline Palms-configuration areas $* \chi^{2}$ tests & 204 & 10 & 3 & 4 & 0 & 2 & 2 & $\overline{0 \cdot 2}$ & 0 & 120 & 6 & 3 & $2 \cdot 4$ & 0 & $1 \cdot 2$ & 4 & $0 \cdot 1$ & 0 \\
\hline Maximum atd angles: analysis of variance & 2 & $0 \cdot 1$ & 0 & 0 & $\overline{0}$ & 0 & $\overline{1}$ & 0 & $\overline{0}$ & 2 & $\overline{0.1}$ & 1 & 0 & 0 & 0 & 0 & 0 & 0 \\
\hline$a b$ ridge counts: analysis of variance & 2 & $0 \cdot 1$ & 0 & 0 & 0 & 0 & 0 & 0 & 0 & 2 & $0 \cdot 1$ & 0 & 0 & 0 & 0 & 0 & 0 & 0 \\
\hline$A-d$ ridge counts: analysis of variance & 2 & 0.1 & 0 & 0 & $\overline{0}$ & 0 & 0 & 0 & 0 & 2 & 0.1 & $\overline{0}$ & 0 & $\overline{0}$ & 0 & $\overline{0}$ & 0 & 0 \\
\hline $\begin{array}{l}\text { Distal palmar loop ridge counts: analysis of } \\
\text { variance }\end{array}$ & 11 & 0.6 & 1 & 0.2 & 0 & 0.1 & 2 & 0 & 0 & 11 & 0.6 & 0 & 0.2 & 1 & 0.1 & 0 & 0 & 1 \\
\hline
\end{tabular}

* Estimate of possible tests based on combining lines of small numbers where the $\chi^{2}$ expected value would be below 5 in any cell. 
computer program, the actual functions are not made available.

An attempt was then made to see whether these differences between the disease groups, summarized in the discriminant function, could be utilized in diagnosis. Prints were provided for 15 male patients, each suffering from one of the diseases which had been studied. The actual diagnosis was not known to the investigator, who therefore analysed the prints blind. Since six diseases were being examined, the chance that any one patient would be correctly assigned to his proper disease was 1 in 6 , so that 2.5 correct assignments by chance would be expected. In fact the diagnosis in two patients was correctly identified and not identified in the remainder. Thus the application of the discriminant function yields only as many accurate classifications as would be expected by chance.

Subsequently the palm and finger patterns of these 15 patients were also classified, and a score was calculated based on the frequency of each item in each disease of the series. In this way diagnostic rankings were produced for each patient, both by using the whole data and by using only those items which had shown significant differences between the disease groups. These rankings agreed neither with each other nor with those produced by the discriminant analyses of ridge counts.

\section{Discussion}

The pronounced differences between the disease series and the failure of the diagnostic trial are not likely to be due to any change with time in the criteria of ridge counting and classifying, though intraobserver error was not in fact measured by any reanalysis. The number of patients included in the series of early onset diabetes is small, but the other groups contain a sufficiently large number of patients to reduce the standard errors of the quantitative variables to acceptably low levels. The late-onset diabetes series was shown by the discriminant function to overlap widely with the other conditions and, in retrospect, this group should perhaps not have been included in the trial. Similarly, since neoplasia is not thought to be a strongly genetic condition, the inclusion of cancer patients in the discriminant analysis may have been unwise. It was justified by the apparent divergence of the cancer patients' dermatoglyphics from the other groups studied.

The explanation may perhaps be sought among the following factors. Though the patients in this study come mainly from Teesside and central County Durham, the catchment areas of the various hospitals and clinics where they were seen are quite widely dispersed, the patients originating from differing localities, and the possibility exists that some of the differences between the clinical series are due to geographic distribution effects (Roberts and Coope, 1973). The converse is also true, that local dermatoglyphic differences may reflect differing incidences of genetically determined diseases in different localities. Also kinship between patients has not been excluded.

Perhaps insufficient data were used to compile the discriminant function, though this seems unlikely as the discriminant analysis showed quite high probabilities for the preferred diagnosis (30 to $90 \%$ ). A possible cause of the unsatisfactory results of the diagnostic trial may lie in multiple pathology. A man may suffer from several genetically determined conditions; he may have diabetes and later develop a duodenal ulcer. It is unlikely that the cancer patients will develop any of the other conditions 0 that have been studied here, but members of the other groups have about a 1 in 7 chance of developing cancer. The concept of multiple group membership is at variance with the fundamental assumptions of discriminant analysis, so that the possibility of multiple pathology among the cases being discriminated introduces a high probability of error when the discriminant function is applied, despite the fact that cases of known multiple pathology were excluded in calculating the discriminant function in order to increase the function's specificity.

Finally, the relevance of dermatoglyphics is not to diagnosis, but to prognosis; not to the definition of existing disease, but to the identification of people with the genetic predisposition to develop certain diseases. Here lies the importance of the investigation of dermatoglyphics in diseases; not the academic identification of associations, but their practical application. If a meaningful association can be established it may be of use in screening, cheaply, populations at risk so that a watch may be kept for the early onset symptoms. This however requires proof that dermatoglyphic characters may furnish a guide to disease. This has not been forthcoming so far from the present investigation.

The author wishes gratefully to acknowledge an $\widetilde{N}$ Upjohn Scholarship of The Royal College of General $N$ Practitioners and a grant for materials from the Newcastle Regional Hospital board; the statistical help of $\mathrm{Mr} \omega$ R. A. McNay; the advice and constant encouragement of Dr Roberts; and the permission of many colleagues in Teesside and County Durham to examine their patients.

\section{REFERENCES}

Achs, R., Harper, R. G., and Siegal, M. (1966) Unusual dermatoglyphic findings associated with rubella embryopathy New England Fournal of Medicine, 274, 148-150. 
Cummins, H. and Midlo, C. (1961). Finger Prints, Palms and Soles: An Introduction to Dermatoglyphics. Dover, New York.

Glanville, E. V. (1965). Hereditary and line A of palmar dermatoglyphics. American fournal of Human Genetics, 17, 420-424.

Holt, S. B. (1961). Quantitative genetics of finger-print patterns. British Medical Bulletin, 17, 247-250.

Mellor, C. S. (1968). Dermatoglyphics in schizophrenia. British fournal of Psychiatry, 114, 1387-1397.

Penrose, L. S. (1954). The distal triradius $t$ on the hands of parents and sibs of mongol imbeciles. Annals of Human Genetics, 19, 1038.
Penrose, L. S. (1967). Finger-print patterns and the sex chromosomes. Lancet, 1, 298-300.

Pons, J. (1964). Genetics of the a-b ridge count on the human palm. Annals of Human Genetics, 27, 273-277.

Roberts, D. F. and Coope, E. (1973). (In press.)

Siegal, S. (1956). Non Parametric Statistics for the Behavioral Sciences, pp. 184-194. McGraw-Hill, Tokyo.

Verbov, J. L. (1970). Dermatoglyphics in leukaemia. Fournal of Medical Genetics, 7, 125-131.

Walker, N. F. (1957). The use of dermal configurations in the diagnosis of mongolism. Fournal of Pediatrics, 50, 19-26. 